\title{
Pengaruh Model Pembelajaran Direct Instruction Terhadap Hasil Belajar Teknik Dasar Guling Depan Senam Lantai
}

\section{The Effect of Direct Instruction Learning Model on Learning Outcomes for the Basic Technique of Forward Roll Gymnastics}

\author{
Mabrur ${ }^{1}$, Anang Setiawan², Mochamad Zakky Mubarok ${ }^{3}$ \\ 1,2,3Program Studi PJKR, STKIP Nahdlatul Ulama Indramayu, Jawa Barat, Indonesia \\ email: mabroer62@gmail.com¹, anangsetiawan@stkipnu.ac.id², mubarokzakky10@gmail.com³
}

doi) : https://doi.org/10.20884/1.paju.2021.2.2.4014

\begin{abstract}
Abstrak
Model pembelajaran menjadi aspek penting dalam mendukung keberhasilan proses dan hasil belajar siswa dalam pembelajaran penjas di sekolah, khususnya pada mata pelajajaran senam lantai di tingkat sekolah dasar. Penelitian ini bertujuan untuk mengetahui pengaruh model pembelajaran direct instruction terhadap hasil belajar teknik dasar guling depan senam lantai secara ilmiah. Penelitian ini menggunakan metode eksperimen dengan desain one group pretest postest. Teknik pengumpulan data dalam penelitian ini menggunakan tes unjuk kerja. Pengujian hipotesis menggunakan paired sample t-test. Populasi penelitian adalah siswa kelas VI UPTD SDN 4 Krangkeng Kecamatan Krangkeng Kabupaten Indramayu Tahun Ajaran 2019/2020. Pengambilan sampel menggunakan teknik total sampling maka didapat 35 siswa sebagai sampel penelitian. Berdasarkan hasil penelitian diketahui bahwa rata-rata hasil senam lantai guling depan yaitu untuk pretest sebesar 26,9 dan posttest 34,8 . Berdasarkan hasil penelitan dapat disimpulkan bahwa tes guling depan senam lantai berada dalam kategori baik 25,71\%, kategori cukup 45,72\% dan kategori kurang $28,57 \%$. Dengan demikian hasil tes pada siswa berada dalam kategori cukup. Rekomendasi dari penelitian ini yaitu perlu diperhatikan tingkat keterampilan motorik siswa dan membandingkan penggunaan model pembelajaran lain yang lebih sesuai.
\end{abstract}

Kata Kunci : Direct instruction, Senam Lantai, Guling Depan

\begin{abstract}
The learning model is an important aspect in supporting the success of the process and student learning outcomes in physical education learning in schools, especially in the subject of floor gymnastics at the elementary school level. This study aims to determine the effect of the direct instruction learning model on the learning outcomes of the basic technique of rolling front floor gymnastics scientifically. This study uses an experimental method with one group pretest postest design. Data collection techniques in this study using performance tests. Hypothesis testing using paired sample t-test. The study population was the 6th grade students of the UPTD SDN 4 Krangkeng, Krangkeng District, Indramayu Regency, Academic Year 2019/2020. Taking the
\end{abstract}

Alamat Koresponden : Program Studi PJKR, STKIP Nahdlatul Ulama Indramayu, Jawa Barat, Indonesia

Email : mabroer62@gmail.com

\section{(c)}

Jurnal Physical Activity Journal (PAJU) This work is licensed under a Creative Commons Attribution 4.0 International License. 
sample using total sampling technique, it was obtained 35 students as the research sample. Based on the results of the study, it is known that the average results of the front roll floor gymnastics are 26.9 for the pretest and 34.8 for the posttest. Based on the results of the research, it can be concluded that the front roll test of floor gymnastics is in the good category $25.71 \%$, enough category $45.72 \%$ and less category $28.57 \%$. Thus the test results on students are in the enough category. The recommendation of this study is that it is necessary to pay attention to the level of motor skills of students and to compare the use of other learning models that are more appropriate.

Keywords : Direct Instruction, Gymnastics, Front Roll

\section{PENDAHULUAN}

Pendidikan jasmani yang dikembangkan di sekolah, memiliki tujuan menyeluruh yaitu keselarasan antara jiwa dan raga. Lebih khusus, tujuan pendidkan jasmani yaitu untuk mengembangakan potensi siswa dalam tiga ranah pendidikan yaitu perkembangan kognitif, afektif dan psikomotor (Abduljabar, 2011; Budi et al., 2019). Pendidikan Jasmani dan olahraga merupakan bagian dari kurikulum standar lembaga pendidikan dasar dan menengah. Mustafa \& Dwiyog (2020) menjelaskan bahwa pendidikan jasmani adalah bagian integral dari keseluruhan proses pendidikan, Pentingnya pelaksnaan pendidikan jasmani disetiap jenjang pendidikan, perlu diperkuat dengan penerapan berbagai model pembelajaran yang sesuai dengan karakteristik setiap mata pelajaran dan perkembangan siswa.

Model pembelajaran merupakan suatu kerangka pembelajaran dengan program yang telah ditentukan. Model pembelajaran adalah deskripsi dari lingkungan belajar yang menggambarkan perencanaan kurikulum, kursus-kursus dan desain unit-unit pelajaran Joyce dan Weil dalam (Ginanjar, 2016a). Model pembelajaran mempunyai empat ciri khusus yang tidak dipunyai oleh strategi atau metode pembelajaran. 1. Rasional teoritis yang logis yang disusun oleh pendidik. 2. Tujuan pembelajaran yang akan dicapai. 3. Langkah-langkah mengajar yang diperlukan sehingga model pembelajaran dapat dilaksanakan secara optimal. 4. Lingkungan belajar yang diperlukan sehingga tujuan pembelajaran dapat dicapai (Saputra, 2020).

Model pembelajaran yang dapat diterapkan dalam pebelajaran pendidikan jasmani memiliki beberapa jenis yang disesuaikan berdasarkan karakteristik materi pembelajaran. Budi \& Listiandi (2021) dan Suherman (2009) menjelaskan bahwa pembelajaran pendidikan jasmani dapat mengunakan model pembelajaran Kooperatf, Peer Teaching, 
Mabrur, Anang Setiawan \& Mochamad Zakky Mubarok | Pengaruh Model Pembelajaran Direct Instruction Terhadap Hasil Belajar Teknik Dasar Guling Depan Senam Lantai

Inquiry, Teaching Game for Understanding (TGFU), Play Teach Play dan Direct teaching. Salah satu model pembelajaran yang dapat digunakan yaitu Direct teaching atau model pembelajaran langsung.

Model pengajaran langsung (direct instruction) dilandasi oleh teori belajar perilaku yang berpandangan bahwa belajar bergantung pada pengalaman termasuk pemberian umpan balik. Model pembelajran direct instruction memiliki tema "teacher as instructional leader" (Metzler dalam Ginanjar, 2016). Jadi bisa dikatakan guru sebagai pemimpin intruksi, didalam model pembelajaran direct instruction guru merupakan sumber mengenai isi pembelajaran, manajemen pembelajaran, dan ketertiban siswa dalam pembelaran. Lebih lanjut Nur et al. (2020) dan Saputra (2020) pembelajaran langsung adalah sebuah model pembelajaran yang berpusat pada guru untuk meningkatkan penguasaan berbagai keterampilan dan pengetahuan yang dimiliki oleh siswa.

Karakteristik model direct instruction yang berpusat pada guru, akan membuat siswa melakukan berbagai gerakan dengan lebih terstruktur. Metode pembelajaran langsung merupakan salah satu cara untuk mengajar efektif karena siswa dapat memahami konsep dan melakukan keterampilan gerak sesuai intruksi dari guru (Wardana, 2015). Berdasarkan hal tersebut maka, model direct instruction atau pembelajaran lansung dapat diterapkan pada mate pelajaran olahraga terukur dan ketangkasan, salah satunya yaitu pembelajaran senam lantai.

Senam adalah suatu rangkaian gerakan melibatkan gerakan fisik seseorang dengan langkah yang sudah tersusun. Senam merupakan jenis olahraga yang bentuk gerakannya dipilih dan disusun secara sistematis berdasarkan prinsip-prinsip tertentu sesuai dengan kebutuhan (Setiawan et al., 2020; Sari \& Sugiarto, 2016). Lebih lanjut Budi (2021) dan Yusuf (2018) mendefinisikan senam sebagai sesuatu latihan tubuh yang dipilih, dilakukan secara sadar dan terencana, disusun secara sistematis dengan tujuan meningkatkan kesegaran jasmani mengembangkan keterampilan, dan menanamkan nilainilai mental spiritual.

Senam terdiri dari 6 macam diantaranya yaitu 1. Senam artistic, 2. Senam ritmik sportif, 3. Senam akrobatik, 4. Senam aerobic sport, 5. Senam trampoline, 6. Senam umum (Margono, 2009; Syaiku, 2010). Dari berbagai jenis senam tersebut, senam artistic dalam bentuk gerakan senam lantai merupakan salah satu materi yang diajarkan di 
sekolah, terutama pada jenjang Sekolah Dasar (SD). Materi senam lantai yang diajarkan pada siswa SD yaitu gerakan guling depan.

Guling depan adalah menggelinding ke depan, dengan posisi badan tetap harus membulat, yaitu kaki dilipat, lutut tetap melekat di dada, kepala ditundukkan sampai dagu menempel di dada (Sapto, 2018). Lebih lanjut Ruslan \& Huda (2019) guling depan adalah gerakan yang dimulai dengan urutan guling depan dari pundak atau tengguk, punggung, pinggang, dan panggul bagian belakang, kemudian mendarat dengan posisi jongkok dan berdiri. Dari pengertian diatas maka dapat disimpulkan guling depan adalah suatu gerakan berputar kedepan dengan awalan berdiri atau dalam posisi jongkok di depan matras dengan kaki selebar bahu kemudian tangan meneyentuh matras dengan awalan tengguk menempel pada matras lakukan dorongan kedepan hingga posisi jongkok atau duduk.

Permasalahan yang terjadi pada siswa sekolah dasar pada saat melakukan gerakan guling depan senam lantai yaitu siswa kurang memahami konsep gerakan senam guling depan, selain itu siswa merasa takut pada saat melakukan gerakan senam. Hasil peneltiian terdahulu menunjukan bahwa kesalahan yang sering terjadi saat melakukan gerakan guling depan adalah siswa tidak membulatkan tubuhnya dengan sempurna (Sari, Sugiarto, \& Purnami, 2003; Yusuf, 2018). Berdasarkan hasil peneltian tersebut maka penting bagi guru untuk menerapkan model pembelajaran yang tepat, terutama model direct instruction.

Hasil penelitian terdahulu menunjukan bahwa model pembelajaran langsung dengan modifikasi bola voli mini memberikan dampak yang signifikan terhadap peningkatan teknik dasar bola voli (Satrianto, 2014). Penelitian lain menunjukan bahwa dengan menggunakan model pembelajaran direct instruction memberikan dampak yang lebih baik dibandingkan dengan model pembelajaran problem base instruction terhadap hasil belajar passing melambung sepak bola (Bagastya \& Indriarsa, 2014).

Penelitian mengenai model pembelajaran telah banyak dilakukan, akan tetapi pada peneltiian ini lebih menekankan kepada penggunaan model direct instruction atau pembelajaran langsung pada materi senam lantai guling depan yang diterapkan pada siswa sekolah dasar. Penerapan model direct instruction pada materi senam lantai guling depan masih jarang dilakukan terutama di daerah Indramayu sehingga perlu dikaji lebih dalam apakah model ini dapat memberikan dampak yang signifikan dalam pencapaian hasil belajar siswa. 
Mabrur, Anang Setiawan \& Mochamad Zakky Mubarok | Pengaruh Model Pembelajaran Direct Instruction Terhadap Hasil Belajar Teknik Dasar Guling Depan Senam Lantai

Berdasarkan permasalahan dan hasil peneltiian terdahulu, maka perlu dilakukan penelitian mengenai penerapan model pembelajaran direct instruction atau model pembelajaran langsung untuk meningkatkan keterampilan gerakan senam lantai guling depan pada siswa sekolah dasar.

\section{METODE}

Metode yang digunakan didalam penelitian ini adalah metode penelitian eksperimen. Penelitian eksperimen adalah metode penelitian yang mencari pengaruh treatment atau perlakuan yang dikendalikan untuk menguji hipotesis hubungan sebab akibat (Ginanjar, 2016). Sampel dalam penelitian ini yaitu siswa Sekolah Dasar kelas VI dengan jumlah 35 orang. Instrumen penelitian yang digunakan yaitu tes keterampilan senam guling depan (Ashandika, 2014).

Peneltian dilakukan dengan terlebih dahulu melaukan tes awal (Pretest) untuk mengetahui kemampuan awal gerakan senam guling depan yang dimiliki oleh siswa. Tahap selanjutnya yaitu melakukan perlakukan (treatment) dengan menerapkan pembelajaran senam menggunakan model direct instruction. Perlakukan dilakukan sebanyak 14 kali pertemuan, sesuai dengan penelitian terdahulu untuk mengetahui peningkatan keterampilan motorik pada pembelajaran senam dan sepakbola (Bayraktar, 2011; Qohhar \& Pazriansyah, 2019).

Teknik pengumpulan datanya berupa tes unjuk kerja, maka siswa dinilai seberapa besar tingkat kemampuan dalam melakukan gerakan guling depan dari tahap persiapan, tahap gerakan, dan tahap akhir gerakan. Penilaian gerakan guling depan dinilai oleh tiga orang ahli yaitu, peneliti, dosen senam STKIP NU Indramayu dan wasit senam tingkat Kabupaten, sehingga data yang diperoleh valid. Kriteria skor dalam gerakan guling depan terlihat pada tabel 1. dibawah ini

Tabel 1. Kriteria Penilaian Senam Guling Depan Adopsi Penilaian Senam Ketangkasan

\begin{tabular}{cccc} 
No & Rentang Skor & Nilai & Kriteria keberhasilan \\
\hline 1 & 45 & $90-100$ & Baik sekali \\
\hline 2 & $44-39$ & $80-89$ & Baik \\
\hline 3 & $38-33$ & $70-79$ & Cukup \\
\hline 4 & $32-27$ & $60-59$ & Kurang \\
\hline 5 & $26<$ & 50 & Kurang sekali
\end{tabular}


Analisi data penelitian menggunakan uji prasarat normalitas dan uji hipotesis yang digunakan yaitu uji paired simple $t$ test untuk mengetahui ada tidaknya pengaruh model pembelajaran direct instruction terhadap peningkatan gerakan guling depan siswa sekolah dasar.

\section{HASIL}

Data penelitian mengenai hasil tes awal dan tes akhir keterampilan guling depan pada siswa SD dengan menggunakan model pembelajaran direct instruction dapat dilihat pada tabel 2. dibawah ini.

Tabel 2. Data Tes Awal dan Akhir Keterampilan Senam Guling Depan

\begin{tabular}{ccccc}
\hline No & Rentang Skor & Kriteria keberhasilan & Tes Awal & Tes Akhir \\
\hline 1 & 45 & Baik sekali & \\
\hline 2 & $44-39$ & Baik & 9 \\
\hline 3 & $38-33$ & Cukup & 4 & 16 \\
\hline 4 & $32-27$ & Kurang & 11 & 10 \\
\hline 5 & $26<$ & Kurang sekali & 20 & \\
\hline
\end{tabular}

Berdasarkan hasil penelitian diketahui bahwa hasil pretest kemampuan siswa dalam melakukan guling depan senam lantai menunjukan hasil 20 siswa atau 57,14 \% siswa dalam kategori kurang sekali, 11 siswa atau 31,44\% dalam kategori kurang, dan 4 orang atau $11,42 \%$ siswa kategori cukup. Hasil posttest kemampuan siswa dalam melakukan guling depan senam lantai memliki kategori baik sebanyak 9 siswa atau 25,71 $\%$, kategori cukup sebanyak 16 orang atau 45,72\%, dan kategori kurang sebanyak 10 siswa atau $28,57 \%$. Berdasarkan data tersebut maka terdapat peningkatan keterampilan senam guling depan secara signifikan. Rata-rata hasil tes pada siswa berada dalam kategori sedang.

Hasil penelitian mengenai data rata-rata dan simpangan baku keterampilan teknik senam guling depan dengan menggunakan model pembelajaran direct instruction pada siswa sekolah dasar ditunjukan pada tabel 3. dibawah ini. 
Mabrur, Anang Setiawan \& Mochamad Zakky Mubarok | Pengaruh Model Pembelajaran Direct Instruction Terhadap Hasil Belajar Teknik Dasar Guling Depan Senam Lantai

Tabel 3. Data Rata-Rata dan Simpangan Baku Hasil Penelitian

\begin{tabular}{lllll}
\hline Variabel & Tes & Rata-Rata & SD \\
\hline Model pembelajaran & direct & Pretest & 26.91 & 4.60 \\
\cline { 2 - 4 } instruction & Posttest & 34.8 & 4.53 \\
\hline
\end{tabular}

Berdasarkan hasil dari rata-rata penelitian pengaruh model pembelajaran direct instruction terhadap keterampilan guling depan senam lantai dari pretest dan posttest maka didapatkan rata-rata pretest yaitu 26.91 dan simpangan baku 4.60. Sedangkan rata-rata posttest yaitu 34.8 dan simpangan baku 4.53. Selanjutnya hasil Uji prasarat normalitas data peneltiian dapat dilihat pada tabel 4. dibawah ini.

Tabel 4. Data Uji Normalitas Data Penelitian

\begin{tabular}{cccccc}
\hline \multicolumn{1}{c}{ Variabel } & Tes & $\mathrm{N}$ & $\mathrm{L}$ hitung & $\mathrm{L}$ tabel & Keterangan \\
\hline $\begin{array}{l}\text { Model pembelajaran } \\
\text { direct instruction }\end{array}$ & Pretest & 35 & 0.9349 & 1.6895 & Normal \\
\cline { 2 - 6 } & Posttest & 35 & 0.8869 & 1.6895 & Normal \\
\hline
\end{tabular}

Berdasarkan perhitungan pretest $\mathrm{L}$ hiutung $=0.9349<\mathrm{L}$ tabel $=1.6895$ maka data diatas berdistribusi normal dan posttest $\mathrm{L}$ hitung $=0.8869<\mathrm{L}$ tabel $=1.6895$ maka data diatas berdistribusi normal. Uji hipotesis peneltiian diperoleh data seperti dalam tabel 5. dibawah ini.

Tabel 5. Data Uji Hipotesis Penelitian

\begin{tabular}{lcccc}
\hline \multicolumn{1}{c}{ Variabel X } & N & T Hitung & T Tabel & Keterangan \\
\hline $\begin{array}{l}\text { Model pembelajaran } \\
\text { direct instruction }\end{array}$ & 35 & -20.415 & 2.032 & Signifikan \\
\hline
\end{tabular}

Berdasarkan perhitungan data diatas $T$ hitung $=-20.415>\mathrm{L}$ tabel $=2.032$ maka data di atas signifikan. Sehingga model pembelajaran direct teaching memiliki pengaruh yang signifikan untuk meningkatkan keterampilan guling depan pada siswa sekolah dasar. 


\section{PEMBAHASAN}

Penelitian menunjukan hasil bahwa terdapat peningkatan keterampilan gerak senam lantai guling depan pada siswa sekolah dasar setelah siswa diberikan perlakukan dengan mengunakan model direct instruction atau pembelajaran langsung. Peningkatan keterampilan gerak senam guling depan yang dialami oleh siswa terjadi karena dalam proses pembelajaran, siswa terlibat aktif dalam melakukan gerakan senam dan dibimbing secara tepat oleh guru. Guru dalam hal ini bertugas sebagai instruktur yang memberikan contoh gerakan, sekaligus sebagai evaluator dalam memperbaiki gerakan senam yang dilakukan oleh siswa (Suherlan, 2019).

Hasil penelitian tedahulu menunjukan bahwa model pembelajaran langsung (direct instruction) secara signifikan dapat meningkatkan hasil belajar senam lantai (Candra \& Firmansyah, 2017). Model direct instruction pada praktiknya memberikan kesempatan kepada siswa untuk dapat melakukan gerakan sesuai dengan teknik yang benar pada saat melakukan gerakan senam, karena pembelajaran keterampilan gerak dilakukan secara bertahap dimulai dari gerakan yang paling mudah menuju gerakan yang kompleks. Hasil penelitian terdahulu menunjukan bahwa model pembelajaran langsung (Direct Instruction) merupakan salah satu pendekatan yang dirancang secara tersusun dan dilaksanakan secara bertahap, sehingga penyampaian pengetahuan atau ilmu menjadi efektif dan efisien (Mirawati \& Royani, 2019; Rahayu, 2018; Sumardiyanto, 2016).

Hasil penelitian juga menunjukan bahwa walaupun terjadi peningkatan, akan tetapi rata-rata keterampilan gerak senam lantai guling depan pada siswa sekolah dasar berada pada katergori cukup baik. Hal ini dikarenakan pada saat proses pembelajaran, tidak semua siswa mengikuti proses pembelajaran dengan baik karena memiliki keterbatasan dengan waktu dan keterampilan motorik. Hasil penelitian terdahulu menunjukan bahwa siswa dengan motorik tinggi memiliki hasil belajar senam lantai lebih baik dari pada siswa dengan motorik rendah (Fajar, 2017; Setiawan et al., 2020). Berdasarkan peneltiian tersebut maka siswa perlu memiliki pondasi gerak yang baik untuk dapat melakukan gerakan senam lantai guling depan.

Selain faktor motorik, kondisi psikologis siswa juga mempengaruhi hasil belajar senam. Berdasarkan pelaksanan pembelajaran dan tes menunjukan anak masih merasa takut pada saat melakukan gerakan senam guling depan, sehingga hasil yang diperoleh 
Mabrur, Anang Setiawan \& Mochamad Zakky Mubarok | Pengaruh Model Pembelajaran Direct Instruction Terhadap Hasil Belajar Teknik Dasar Guling Depan Senam Lantai

kurang maksimal. Hasil peneltiian menunjukan bahwa keterampilan gerak senam lantai dipengaruhi oleh tingkat kecemasan siswa pada saat melakukan gerakan (Irsanto, 2015; Nigerukebede, 2016).

Berdasarkan data dilapangan dan didukung hasil penelitian terdahulu maka peningkatan keterampilan gerak senam lantai guling depan pada siswa sekolah dasar dipengaruhi oleh model pembelajaran yang tepat dan didukung dengan tingkat keterampilan motorik serta faktor psikologis pada diri siswa.

\section{SIMPULAN}

Bedasarkan dari data hasil penelitian dan pembahasan dapat disimpulan bahwa model pembelajaran direct instruction memberikan pengaruh terhadap hasil belajar teknik dasar guling depan senam pada siswa sekolah dasar. Secara keseluruhan tingkat keterampilan teknik dasar senam lantai guling yang dimiiki siswa berada pada kategori cukup baik, sehingga model pembelajaran direct instruction dapat diterapkan pada pembelaajran senam. Rekomendasi untuk penelitian selanjutnya yaitu dapat menerapkan model direct instruction pada materi pembelajaran dengan jenis olahraga terukur dan beladiri yang diterapkan pada siswa SMP maupun SMA.

\section{REFERENSI}

Abduljabar, B. (2011). Pengertian pendidikan jasmani. IImu Pendidikan.

Ashandika, D. (2014). Penerapan Media Bantu Untuk Meningkatkan Keterampilan Guling Depan Senam Lantai Pada Siswa Kelas V A SDN 1 Kota Bengkulu. Skripsi: UNB.

Bagastya, D. A., \& Indriarsa, N. (2014). Perbandingan model pembelajaran direct instruction (DI) dan problem base instruction (PBI) terhadap hasil belajar passing melambung sepak bola kelas IX SMPN 1 Sugio Lamongan. Jurnal Pendidikan Olahraga Dan Kesehatan, 2.

Bayraktar, G. (2011). The effect of cooperative learning on students approach to general gymnastics course and academic achievements. Educational Research and Reviews, $6(1), 62-71$.

Budi, D. R. (2021). Evaluasi Pembelajaran Senam di Masa Pandemi Covid 19 Berbasis eLearning Eldiru. 1-7. https://doi.org/10.31219/osf.io/qtb46

Budi, D. R., Hidayat, R., \& Febriani, A. R. (2019). The Application of Tactical Approaches in Learning Handballs. JUARA: Jurnal Olahraga. https://doi.org/10.33222/juara.v4i2.534 
Budi, D. R., \& Listiandi, A. D. (2021). Model Pembelajaran Dalam Pendidikan Jasmani. https://doi.org/https://doi.org/10.31219/osf.io/xzh3g

Candra, S. W., \& Firmansyah, H. (2017). Pengaruh Model Pembelajaran Langsung (Direct Intruction) dan Model Pembelajaran Inkuiri (Indirect Intruction) Terhadap Hasil Belajar Pembelajaran Senam di SMAN 1 Haurgeulis. Thesis, Universitas Pendidikan Indonesia. Retrieved from http://repository.upi.edu/23807/

Fajar, M. (2017). Peranan Intelegensi Terhadap Perkembangan Keterampilan Fisik Motorik Peserta Didik Dalam Pendidikan Jasmani. Multilateral Jurnal Pendidikan Jasmani Dan Olahraga. https://doi.org/10.20527/multilateral.v16i1.3664

Ginanjar, A. (2016a). Modul Implementasi Praktis Model-model Pembelajaram Pendidikan Jasmani. Indramayu: STKIP NU Indramayu.

Ginanjar, A. (2016b). Modul Penelitian Kuantitatif Pendidikan Jasmani. Indramayu: STKIP $\mathrm{NU}$ Indramayu.

Irsanto, Y. (2015). Peningkatan Hasil Belajar Senam Lantai Gerakan Roll Belakang Dengan Menggunakan Alat Bantu Spon Dan Karet Ban Dalam Sepeda Motor Pada Siswa Sd Negeri Srondol 02 Kota Semarang Tahun Ajaran 2013/2014. Journal of Physical Education, Sport, Health and Recreations, 4(6), 1845-1854.

Margono, A. (2009). Senam. Surakrta: UNS Press.

Mirawati, B., \& Royani, I. (2019). Pengembangan LKS Biologi SMA Berbasis Praktikum dengan Model Pembelajaran Langsung untuk Meningkatkan Keterampilan Proses Sains Siswa. Urnal Penelitian Dan Pengkajian IImu Pendidikan: E-Saintika, 3(2), 8895. https://doi.org/https://doi.org/10.36312/e- saintika.v3i2.152

Mustafa, P. ., \& Dwiyog, W. . (2020). Kurikulum Pendidikan Jasmani, Olahraga, dan Kesehatan di Indonesia Abad 21. Jurnal Riset Teknologi Dan Inovasi Pendidikan (JARTIKA, 3(2), 422-438.

Nigerukebede, D. (2016). Identifying Obstructs That Affect the Effectiveness of Grade 12th Students Performance on the Practical Class of Apparatus Gymnastic Activities in Adet Preparatory School. IOSR Journal of Sports and Physical Education (IOSRJSPE), 3(6), 51-56.

Nur, L., Malik, A. A., Juditya, S., Kastrena, E., Widyawan, D., Agustan, B., ... Yang, C. B. (2020). Comparison of two types of instruction in physical education. International Journal of Psychosocial Rehabilitation, 24(10), 1785-1793. https://doi.org/10.37200/IJPR/V24I10/PR300205

Qohhar, W., \& Pazriansyah, D. (2019). Pengaruh Model Pembelajaran Kooperatif Tipe Teaching Games For Understanding (TGFU) Terhadap Peningkatan Hasil Belajar Teknik Dasar Sepakbola. Physical Activity Journal. https://doi.org/10.20884/1.paju.2019.1.1.1998 
Mabrur, Anang Setiawan \& Mochamad Zakky Mubarok | Pengaruh Model Pembelajaran Direct Instruction

Rahayu, D. W. (2018). Penerapan Model Pembelajaran Langsung Untuk Meningkatkan Kreativitas Anak Sekolah Dasar. Proceedings of the ICECRS, 1(3), 137-142. https://doi.org/https://doi.org/10.21070/picecrs.v1i3.1372

Ruslan, R., \& Huda, M. S. (2019). Penerapan Metode Bermain Dalam Meningkatkan Hasil Belajar Guling Depan (Forward Roll). Halaman Olahraga Nusantara (Jurnal IImu Keolahragaan), 2(1), 10. https://doi.org/10.31851/hon.v2i1.2461

Sapto, A. (2018). Bentuk-Bentuk Dasar Gerakan Senam. Malang.

Saputra, H. (2020). Model Pembelajaran Direct Intruction Dan Model Pembelajaran Tgt Teams Games Tournament Terhadap Peningkatan Kemampuan Keterampilan LayUp Shoot Dalam Permainan Bola Basket Pada Siswa Kelas Xi Smk Pasundan 1 Cianjur. Maenpo, 8(2), 16. https://doi.org/10.35194/jm.v8i2.925

Sari, W. K. S., Sugiarto, T., \& Purnami, S. (2003). Rangkaian Gerakan Senam Sederhana Siswa Kelas VIII di SMP. Jurnal Pendidikan Jasmani, 26(1). Retrieved from https://doi.org/http://dx.doi.org/10.17977/pj.v26i1.7726.g3545

Satrianto, M. (2014). Pengaruh Model Pembelajaran Langsung Dengan Menggunakan Modifikasi Bolavoli Mini Terhadap Hasil Belajar Servis Bawah. Jurnal Pendidikan Olahraga Dan Kesehatan, 2.

Setiawan, A., Yudiana, Y., Ugelta, S., Oktriani, S., Budi, D. R., \& Listiandi, A. D. (2020). Hasil Belajar Pendidikan Jasmani dan Olahraga Siswa Sekolah Dasar: Pengaruh Keterampilan Motorik (Tinggi) dan Model Pembelajaran (Kooperatif). TEGAR: Journal of Teaching Physical Education in Elementary School. https://doi.org/10.17509/tegar.v3i2.24513

Suherlan, E. (2019). Pengaruh Perbandingan Antara Model Pembelajaran Direct Instruction Dengan Model Project Based Learning Terhadap Hasil Belajar Backhand (Tenis Meja) Pada Siswa Kelas Iv Sd Negeri Cipaku Kecamatan Sukaraja. Jurnal PAJAR (Pendidikan dan Pengajaran). https://doi.org/10.33578/pjr.v3i5.7889

Suherman, A. (2009). Revitalisasi Pengajaran dalam Pendidikan Jasmani. Bandung: CV. Bintang Warli Artika.

Sumardiyanto. (2016). Pengaruh Model Peer Teaching dan Model Direct Instruction Terhadap Hasil Belajar Keterampilan Dasar Senam Lantai dan Self Efficacy Siswa. Tesis. UPI: Bandung.

Syaiku, A. (2010). Seri Olahraga Senam. Bogor: CV. Kaldera.

Wahyu Heny Kartika Sari, Tatok Sugiarto, S. P. (2016). Pengembangan Pembelajaran Senam Lantai Rangkaian Sederhana Siswa Kelas VIII di SMP Negeri 2 ngoro Kabupaten Mojokerto. Jurnal Pendidikan Jasmani. 
Wardana, S. (2015). Peningkatan Hasil Belajar Passing Pada Permainan Sepak bola Melalui Metode Pembelajaran Langsung Siswa Kelas V SDN Tulangan li Sidoarjo. Jurnal Pendidikan Olahraga Dan Kesehatan, 3.

Yusuf, Y. (2018). Peningkatan ketrampilan senam lantai siswa kelas VI SDN Dempelan 01 melalui pembelajaran langsung dengan metode JIGSAW. Premiere Educandum: Jurnal Pendidikan Dasar Dan Pembelajaran, 8(1), 54. https://doi.org/10.25273/pe.v8i1.2366 